Norbert Widok (Opole)

\title{
Christian Family as Domestic Church in The Writings of St. John Chrysostom
}

The family ${ }^{1}$ has always been the place of the transmition of values, be it human, social, and religious. This statement refers also to the patristic period, i.e. to the first ages of Christianity ${ }^{2}$. John Chrysostom ( $\left.\uparrow 407\right)$, the most famous preacher in the East, is an example of a bishop who exerted an important influence on the formation of family. In his homilies he instructed fathers and mothers about their pedagogical tasks, and spoke of religious upbringing of children, which was directly linked with the well being of Christian family. His comments on the letters of St. Paul, his favourite biblical author, brought out the significant inspirations and ideas concerning topics connected with family and raising children.

\section{1. "Domestic Church" in the letters of St. Paul}

In his letters sent to various Christian communities St. Paul employs the notion of the "Church" in relation to familial environment. In his Letter to the Romans, where he sends greetings to Priscilla and Aquilla, he adds the following words: and my greetings to the church at their house (Rom 16, 5). The word "Church," according to the ecclesiological terminology of that epoch, stood for the community of the baptised who gathered for liturgical meetings. This Eucharistic gatherings took place at private homesteads. The ecclesiastical community met at a house of one of its members. St. Paul's greetings informs that Priscilla and Aquilla had a house where the Roman community got together for prayers.

\footnotetext{
1 The shorter, Polish version of this article was given in SacP 5, 2012, p. 25-29.

2 See: T.A. Sabattini, La familia cristiana nell' "Apologetico" di Tertulliano, RSC 23, 1975, p. 51-66; M. Forlin Patrucco, Aspetti di vita familiare nel IV secolo negli scritti dei Padri Cappadoci, [in:] Etica sessuale e matrimonio nel cristanesimo delle origini, ed. R. Cantalamessa, Milano 1976, p. 158-179; M. Mees, Clemens von Alexandrien über Ehe und Familie, Aug 17, 1977, p. 113-131; L. Cignelli, La "Famiglia-modello" nella Chiesa patristica, LAn 32, 1982, p. 155-190; M. ТАцвот, The Byzantine family and the monastery, DOP 44, 1990, p. 119-130; A. Swoboda, Rodzina w pismach Ojców Apostolskich, CT 72.4, 2002, p. 37-48; J.C. CAvAdini, The sacramentality of marriage in the Fathers, PE 17, 2008, p. 442-463; C. Osıeк, What We Do and Don't Know about Early Christian Families, [in:] A Companion to Families in the Greek and Roman Worlds, ed. B. Rawson, Oxford 2011, p. 198-213.
} 
The married couple Priscilla and Aquilla is also mentioned in the first Letter to Corinthians, where St. Paul writes: The churches of Asia send their greetings. Aquila and Prisca send their best wishes in the Lord, together with the church that meets in their house $(1$ Cor 16, 19). After anti-Jewish decrees of Claudius, Priscilla and Aquilla left Rome for Corinth, where they met the local community, and later together with Paul they travelled to Ephesus, where St. Paul wrote this letter. The statement about the fact that the local Church met at the house of Priscilla and Aquilla ${ }^{3}$ is essential for the topic of this article. As in the Letter to the Romans, here the words "home" and "Church" were put together again.

A similar content is contained also in the greetings closing the Letter to the Colossians, where its author puts down the following words: Please give my greetings to the brothers at Laodicea and to Nympha and the church which meets in her house (Col $4,15)$. The message of this passage is very clear: at the house of Nimpha in Laodicea Christians met for Eucharist. Here the two notions in question, "Church" and "house", are linked again, which indicates the awareness that it was only the house of a trustworthy follower of Christ that could offer the place of gatherings for local ecclesiastic community.

The development of the situations described above was quite natural ${ }^{4}$. Cordiality and hospitality, and most of all love, as taught by Christ, were obvious reasons for opening the home for others for participation in Christian mysteries ${ }^{5}$. Nobody suggested to perform those mysteries in other buildings than private, because only such were accessible. It was only in Laodicea that in-between 360 and 370, that forbade in one of its cannons (can. 58) to perform Eucharist at private houses ${ }^{6}$.

\section{The notion of "domestic church" in St. John Chrysostom's homilies}

Commenting on St. Paul's letters, especially on the formulas mentioned above, employing the terminology of St. Paul, Chrysostom created analogous references between the words "church" and "house" from the perspective of his time.

The primary text, in which Chrysostom emphatically juxtaposes these two concepts, is a passage from the homily on the First Letter to Timothy. He conveyed there the following instruction:

For the Church is, as it were, a small household, and as in a house there are children and wife and domestics, and the man has rule over them all; just so in the Church there are women, children, ser-

3 M. GärTnER, Die Famielienerziehung in der Alten Kirche, Köln-Wien 1985, p. 11.

4 P. LAMPE, Zur gesellschaftlichen und kirchlichen Funktionen der „Familie” in neutestamentlichen Zeit, Ref 31, 1982, p. 535-542; W. Vogler, Die Bedeutung der urchristlichen Hausgemeinden für die Ausbreitung des Evangeliums, TLz 107, 1982, p. 785-794.

5 See more H.-J. KLAUCK, Kościót domowy w okresie przedkonstantyńskim, VP 5, 1985, p. 177-186.

6 Ibidem, p. 187. 
vants. And if he that presides in the Church has partners in his power, so hath the man a partner, that is, his wife. [...] so there are in a family servants, and daughters... ${ }^{7}$

The content of this text presents similarities between ecclesiastic community and familial community. Both in the former and the latter there exists specific bond between their members. In both of them there is a leader responsible for any activities regulating their everyday life. Chrysostom as a presbyter and later a bishop knew the functioning of the Church. Therefore, he saw the same structure of administration in the life of a house and family. The function of a superior, i.e. of the one responsible for various undertakings of moral and religious nature, was given by him to the father of the family. His co-worker is his wife, with whom he should take care of their sons and daughters, and even servants.

One has to acknowledge that such position of father of the family was not a new discovery, since in the ages before Christ there existed an institution of father known as pater familias. The Antiochian was fully aware of it. His merit consisted in bestowing new functions to the father flowing from baptism, therefore from the confession of faith in the Triune God. With this fact a wide range of additional responsibilities of religious character was connected. It is the father that is, according to Chrysostom, responsible for these. In this way he becomes a superior in the house similarly to a bishop in the local Church.

Similar thought were conveyed in his other commentary on St. Paul's letters, where family was directly named by him as the Church. His words are very suggestive:

Govern thy wife, and thus will the whole house be in harmony. Hear what Paul saith: And if they would learn anything, let them ask their own husbands at home. If we thus regulate our own houses, we shall be also fit for the management of the Church. For indeed a house is a little Church. Thus it is possible for us by becoming good husbands and wives, to surpass all others. ${ }^{9}$

This passage shows that St. Paul became an important inspiration for Chrysostom's ideas concerning the religious life of the family. The burden of responsibility fell on the shoulders of the husband, whose one of the tasks, as he writes, is instruction of his wife. It is not, however, a one-sided activity. Husbands and wives are to sanctify each other, as he adds further in the text ${ }^{10}$. The role of father consists

\footnotetext{
7 John Chrysostom, Homilies on 1 Timothy, 10, 5 (trans. Ph. Schaff, [in:] NPNF, vol. XIII, p. 764).

8 See A. Żurek, Od „paterfamilias” do „Pater noster”. Kontekst kulturowy pojęcia Boga jako „naszego Ojca” w literaturze patrystycznej, SAC 15, 2001, p. 18-28; B. CzyżEwski, Pater familias i jego zadania według św. Jana Chryzostoma, VP 29, 2009, p. 205-222.

9 John Chrysostom, Homily 20 on Ephesians, 6 (trans. Ph. Schaff, [in:] NPNF, vol. XIII, p. 276).

10 More: V. Karras, Male domination of women in the writings of Saint John Chrysostom, GOTR 33, 1991, p. 131-139; C. Broc, Le rôle des femmes dans l'Eglise de Constantinople d'après la correspondance de Jean Chrysostome, [in:] SP 27, 1993, p. 150-154; D.C. ForD, Women and Men in the Early Church: The Full Views of St. John Chrysosom, South Canaan 1996; C.L. DE WET, Wives and the "Hausetafeln” in John Chrysostom 's „Homilia in Epistulam ad Ephesios 20”, APB 21.2, 2010, p. 51-60.
} 
in inspiring other members of the family to activity. In this way, the father becomes an administrator of the house. In such context there appeared his most important statement that the family is a small Church.

Therefore, one can speak of a macro-Church refering to the entire local community and a micro-Church which is the family and its house. By comparing these institutions Chrysostom arrived at a conclusion that the former is administered by a bishop while the latter by the father of the family ${ }^{11}$. In other words, the father of the family performs the role of bishop, i.e. the one who gives instructions concerning religious truths and takes care of the morality of all the members of the family ${ }^{12}$. It is important to emphasize that Chrysostom also included to the domestic Church servants who work in a given family. According to him all the inhabitants of the household should be taken care of by the father.

\section{Episcopal functions of father in the "domestic Church"}

The father of the family performs the function of bishop, when he organizes religious the life of his domestic community. His sanctifying activities can be presented as three tasks: he should take care of the reading of the Holy Scriptures, the practice of prayer, and the catechesis. Obviously, the father cannot perform liturgical activities connected with the Sacraments.

Undoubtedly, the first commentator of the Holy Scriptures in ecclesiastic community is the bishop. He is the one who watches over appropriate interpretation of the word of God making sure that it does not to fall into theological errors and create heresy or schism. In homilies bishop comments on the word of God and thus he fulfils this task. Within the domestic church this function is performed by the father. He, after returning home from church, should - as taught by Chrysostom - set two tables: a table for food and a table for instruction. By this second one he should present what has been said with the words of the bishop. In this way his wife, children and even the servants will not be deprived of the instruction of the bishop, and the family home, due to such father's attitude, will become the church ${ }^{13}$. This statement gives specific responsibilities to the father of the family concerning the Word of God received in liturgy. It should be transmitted in familial community at the so-called table of teaching. It was obvious that there was a table for meals while a table of teaching could be a place

${ }^{11}$ Some elements of this problem are given in paragraph Ojciec rodziny w "Konstytucjach Apostolskich” by J. ŻELAZNY in his book under title Biskup Ojcem. Zarys eklezjologii syryjskiej na podstawie „Konstytucji Apostolskich", Kraków 2006, p. 103-144.

12 See more: O. Pasquato, Pastorale familiare: testimonianza di Giovanni Crisostomo, Sal 51, 1989, p. 3-46.

${ }^{13}$ John Chrysostom, Homilies on Genesis, VI, 2 (The Fathers of the Church, trans. R.C. HiLL, vol. LXXIV, Washington 1999). 
where there was the Bible accessible to all. It could also stand for a particular time during the day devoted to reflection over Biblical texts. The table of teaching was then an extension of the pulpit. If the pulpit served as the place of instruction of the bishop, the table of teaching served for the father's meditation on the Bible. His task was to transmit to his wife, children and servants the conclusions flowing from the study of the Scriptures, being the food for the spirit. In this way, the household becomes a church within which salvation of the members of the familial circle was carried out. It was, therefore, the highest responsibility similar to the one of bishop.

Although the study and meditation on the Holy Scriptures is the father's task, in other homilies Chrysostom entrusts the role of upholding piety at home also to the wife. He adds:

And let the man, as soon as he has risen from his bed, seek after nothing else, but how he may do and say something whereby he may render his whole house more reverent. The woman again, let her be indeed a good housekeeper; but before attending to this, let her have another more needful care, that the whole household may work the works of Heaven. ${ }^{14}$

The wife should help her husband in performing such important task ${ }^{15}$. Chrysostom lays the stress on deeds, i.e. on implementing what was shown in homily and domestic reflection over the Bible. What is visible here is division of functions: the husband takes care of the meditation on the Word of God and the wife puts this into practice in domestic life ${ }^{16}$. Theoria and praxis, the two principles of the Eastern spirituality are revealed here. This practice is the wide opening of oneself to others by the deeds of mercy which should proceed from truly Christian family ${ }^{17}$.

Chrysostom does not confine his teaching to the reading of the Bible. He also writes of the good fruits of such practice. For he believes that a word from the divine Scriptures, made to sound in the ear, doth more than fire soften the hardened soul, and renders it fit for all good things ${ }^{18}$. According to him, holy texts possess the power to transform the spiritual sphere of listeners and to create attitudes open to any good.

Apart from reading and meditating on the Holy Scriptures another very important factor that shapes the spiritual aspect of the family is prayer. Chrysostom confronts participation in promiscuous feasts with feast accompanied by prayer:

${ }_{14}$ John Chrysostom, Homilies on the Gospel of Saint Matthew, LXXVII, 6 (trans. G. Prevost, M.B. RiddLe, [in:] NPNF, vol. X, p. 815).

15 J. Jurkiewicz, Mater familias według św. Jana Chryzostoma, VP 29, 2009, p. 223-232; T. KrynickA, Przymioty i zadania żony wedlug Jana Chryzostoma, VP 29, 2009, p. 113-122.

16 P. Brown, The Body and Societ: Men, Women and Sexual Renunciation in Early Christianity, New York 1988, p. 311-312.

17 H. Wójtowicz, Zadania rodziny chrześcijańskiej w nauczaniu św. Jana Chryzostoma, VP 5, 1985, p. 213-214.

${ }_{18}$ John Chrysostom, Homilies on the Gospel of Saint Matthew, II, 6 (trans. G. Prevost, M.B. Riddle, [in:] NPNF, vol. X, p. 38). 
But how then can one rejoice? Why, by saying hymns, making prayers, introducing psalms in the place of those low songs. Thus will Christ also be at our table, and will fill the whole feast with blessing, when you prayest, when you singest spiritual songs, [...]. So you will make the party a Church, by hymning, in the room of ill-timed shouts and cheers, the Master of all things. ${ }^{19}$

This statement sounds very radical. One has an impression that Chrysostom denies his listeners full participation in social meetings. In fact, the bishop brings them up to be able to participate in them in an appropriate manner. His criticism is directed against those feast which are the time of those low songs or ill-timed shouts and cheers. Instead of such behaviour leading to spiritual destruction he offers prayer of a very concrete form. He encourages the singing of hymns and psalms ${ }^{20}$, i.e. to recitation of texts based on the Holy Scriptures. When introduced into domestic feasts, such elements will give praise to the Lord for all things and all the participants will be filled with blessing. In this way the house where the family enjoys feasts will become a Church. It is the father or the mother that perform here the role of inspiration.

Prayer is also the way of overcoming the difficulties of life. John the bishop persuades his listeners into believing that what is accessible to each man is

the assistance derived from persevering prayers. Thus, we are not ourselves [...] to strive alone, but also to invoke the help from above: and it will surely come and be present with us, and will aid us in our struggles, and make all easy. ${ }^{21}$

The Antiochian teaches about the meaning of prayers and its fruits, so necessary for everyday life. He adds, however, that these should be persevering prayers, being continuous activity of a Christian, and not only a practice in the moment of tragic occurrence. It is only incessant prayer and continuous invocation for help from heaven that turns out to be the firm support brining help in everyday tasks.

Chrysostom himself taught his listeners about the proper attitude at prayer:

Let us, I say, fall down before Him both in body and in mind, that He may raise us up when we are down; let us converse with all gentleness and meekness. And who is so wretched and miserable, one may say, as not to become gentle in prayer? ${ }^{22}$

Both in his exterior port and spiritual attitude one has to exercise modesty, and gentleness, which testify to the humility of a believer. Regardless of the actual status of an individual, his ill fate or happiness, modesty should be a major virtue.

\footnotetext{
19 John Chrysostom, Homilies on Paul's Epistle to the Romans, XXIV, 3 (trans. J.B. Morris, W.H. Simcox, G.B. Stevens, [in:] NPNF, vol. XI, p. 921-922).

20 S. Longosz, Śpiew w rodzinie środkiem wychowania w pedagogii św. Jana Chryzostoma, RNR 1, 2009, p. $1-42$.

21 John Chrysostom, Homilies on the Gospel of Saint Matthew, XXIII, 4 (trans. G. Prevost, M.B. RIDDLE, [in:] NPNF, vol. X, p. 288).

${ }^{22}$ John Chrysostom, Homilies on the Gospel of Saint Matthew, LI, 6 (trans. G. Prevost, M.B. Riddle, [in:] NPNF, vol. X, p. 564).
} 
In family as domestic church, with the practice of reading the Holy Scriptures and praying, the members of the household will turn out to be faithful to Christian principles. According to Chrysostom it is the father as a religious guide that is supposed to watch over them. Commenting on the Letter to the Romans, regarding the houses which gave shelter to Christians in the times of St. Paul, the Antiochian referred also to familial communities of his day. For St. Paul was not in the habit of calling any houses Churches, save where there was much piety, and much fear of God deeply rooted in them ${ }^{23}$. Chrysostom shared this conviction, and confirmed the principle that the house of Christians as domestic church should penetrated by sublime religiosity and deep fear of $\operatorname{God}^{24}$. This requirement is offered to Christians with detailed explanation of its realization.

The appropriate level of religiosity is connected with the transmission of catechetical teachings to the younger generation. The father of the family is responsible for the systematic upbringing of his children leading to the practice of the principles of Christian religion. John Chrysostom preaches with expertise that the father, by providing the boy these teachings, educates himself and proceeds in the good: he becomes better, if not for the love of virtue, then for the love of a child, because he does not want to aggravate him by bad example $^{25}$. The words come from a treaty On Education of Children, which is entirely devoted to pedagogical issues. It is mainly addressed to the father, although there are numerous references to the mother, who should be involved in the process of raising the children. Therefore, at the beginning of this statement there is the phrase these teachings, which closes various instructions directed to the father explaining the way he should take care of proper religious and social attitude of his children ${ }^{26}$. Furthermore, the quoted passage contains a thought about constant pursuit of good and virtue. Virtue is often mention in St. John's homilies. It is understood by him as the integral fullness of perfection consisting of small elements of spiritual faculties, which is documented by a fragment of his homily:

\footnotetext{
${ }^{23}$ John Chrysostom, Homilies on Paul's Epistle to the Romans, XXX, 3 (trans. J.B. Morris, W.H. SimCox, G.B. STEvens, [in:] NPNF, vol. XI, p. 974).

${ }^{24}$ See more: A. Bober, Rodzina kościołem domowym według św. Jana Chryzostoma, VP 5, 1985, p. 193-199; S. Longosz, Rodzina wczesnochrześcijańska Kościołem domowym, RT.KUL 51, 10, 2004, p. 36-50; P. Szczur, Problematyka społeczna w późnoantycznej Antiochii na podstawie nauczania homiletycznego Jana Chryzostoma, Lublin 2008, p. 293-360; S. Longosz, Rodzina kościołem domowym w myśli Jana Chryzostoma, VP 29, 2009, p. 281-312.

${ }^{25}$ John Chrysostom, On Education of Children, 70.

${ }^{26}$ More about problems in these treaty see: Th. Halton, St. John Chrysostom on education, CER 61, 1963, p. 163-175; A. UCIECHA, Rodzina miejscem wychowania w traktacie pedagogicznym „O wychowaniu dzieci" św. Jana Chryzostoma, ŚSHT 19/20, 1986/1987, p. 65-92; T. KoєosowsKI, Wychowanie religijno-moralne dzieci w rodzinie w świetle traktatu „O wychowaniu dzieci” św. Jana Chryzostoma, Sem 17, 2001, p. 405-420; S. WAsilewsкi, Metody wychowawcześw. Jana Chryzostoma, VP 29, 2009, p. 433-445.
} 
And why do I speak of the whole code. For even a part of it overlooked brings upon one great evils; as, for instance, almsgiving overlooked casts into hell them that have come short in it; and yet this is not the whole of virtue, but a part thereof. [...] Again, not to revile is a very small part of it [...]. Again, even continence itself is a part, [...]. I mean, that not only one of them overlooked shuts Heaven against us, but though it be done, yet not in due perfection and abundance, it produces the selfsame effect again. ${ }^{27}$

The three examples of particular virtues (almsgiving, self-control, and abstention from malediction) point to the connection of various spiritual behaviours or psychological attitudes which comprise perfection of the human person. The Antiochian presupposed the long way of gaining such perfection. However, he emphasised the necessity of due perfection and abundance. The perfection and the abundance are elements of general notion of virtue. The bishop wanted his listeners to show perfection of life and high degree of morality ${ }^{28}$.

Apart from the care about moral image of the family Chrysostom also took care also of its faith. In the same homily he expressed important instruction concerning this issue:

Wherefore I entreat you let us use much diligence both to stand in the right faith, and to show forth an excellent life. For unless we add also a life suitable to our faith, we shall suffer the extremest punishment. ${ }^{29}$

He puts together two aspect of the essence of Christianity, namely faith and morality. These two are factors of everyday Christian life that are dependent on each other and which one has to pursue ardently. Undoubtedly this task belonged to the father of the family who performed in family the function similar to the one of the bishop in the local Church.

The analyses of Chrysostom's chosen texts presented above, show the significance of Christian upbringing. They speak of religious upbringing of children, which is directly linked with the well being of the Christian family. Commenting on St. Paul's letters, he started propagating the idea of "domestic church," since it performs the role of a place where sanctification of human being occurs. The father of the family performs in such situation the tasks of a bishop, i.e. a guide in religious life. He should take care of the reading of the Holy Scriptures, the practice of prayer and catechetical teaching, which lead to proper level of faith and Christian morality. According to Chrysostom, systematic introduction of these religious

27 John Chrysostom, Homilies on the Gospel of Saint Matthew, LXIV, 4 (trans. G. Prevost, M.B. RIDDLE, [in:] NPNF, vol. X, p. 377).

28 O. Pasquato, La priorità dell' educazione morale in Giovanni Crisostomo, [in:] Crescita dell' uomo nella catechesi dei Padri, ed. S. Felici, Roma 1998, p. 5-35.

${ }^{29}$ John Chrysostom, Homilies on the Gospel of Saint Matthew, LXIV, 4 (trans. G. Prevost, M.B. RIDDLE, [in:] NPNF, vol. X, p. 684). 
practices in the family contributes to increase in piety among members, as well as social responsibility. The well formed family offers proper foundation for the transmission of religious tradition and significant link in social relations.

\title{
Translated by Wacław Grzybowski
}

\begin{abstract}
John Chrysostom, the most famous preacher of the Eastern Empire, exerted an important influence on the formation of family. In his homilies he instructed fathers and mothers about their pedagogical tasks, and spoke of religious upbringing of children, which was directly linked with the well being of Christian family. Commenting on St. Paul's letters, he started propagating the idea of "domestic church," since it performs the role of a place where sanctification of human being occurs. The father of the family performs in such situation the tasks of a bishop, i.e. a guide in religious life. He should take care of the reading of the Holy Scriptures, the practice of prayer and catechetical teaching, which lead to proper level of faith and Christian morality. According to Chrysostom, systematic introduction of these religious practices in the family contributes to increase in piety among members, as well as social responsibility. The well formed family offers proper foundation for the transmission of religious tradition and significant link in social relations.
\end{abstract}

Norbert Widok

Katedra Historii Kościoła i Patrologii Wydział Teologiczny

Uniwersytet Opolski

ul. Drzymały 1a 45-342 Opole, Polska nwidok@uni.opole.pl 